\title{
Services Rendered by the Government Agencies for the Benefit of Apple Production in Kashmir, India
}

\author{
Zahoor Ahmad Shah ${ }^{1 *}$, Mushtaq Ahmad Dar', Mohd Afzal Beigh ${ }^{1}$, Showket Maqbool ${ }^{2}$, \\ Pradeep Kumar Singh ${ }^{3}$ and Sheikh Muzaffar Ahmad ${ }^{4}$ \\ ${ }^{1}$ Division of Agricultural Extension and Communication SKUAST Kashmir, India \\ ${ }^{2}$ Division of Agricultural Statistics, ${ }^{3}$ Division of Vegetable Sciences, ${ }^{4}$ Associate Director, \\ Extension, SKUAST Kashmir, India \\ *Corresponding author
}

\begin{tabular}{|c|c|}
\hline & A B S T R A C T \\
\hline $\begin{array}{l}\text { Ke y w o r d s } \\
\text { Apple growers, } \\
\text { Government } \\
\text { Services, Kashmir, } \\
\text { India }\end{array}$ & $\begin{array}{l}\text { Apple is considered as one of the most important and widely grown fruit in temperate } \\
\text { zones of the world. The state of Jammu and Kashmir comprising of temperate, cold arid } \\
\text { and hilly areas is capable of producing best quality of apple than rest of the states of the } \\
\text { country. The present study was conducted in } 2017-18 \text { from nine villages of three (3) } \\
\text { districts in Kashmir valley. The data was collected from three hundred (300) apple } \\
\text { growers. A multistage sampling procedure was adopted for the selection of sample }\end{array}$ \\
\hline Article Info & for the benefit of apple production in Kashmir. The study reveals that among all the three \\
\hline $\begin{array}{l}\text { Accepted: } \\
17 \text { April } 2019 \\
\text { Available Online: } \\
10 \text { May } 2019\end{array}$ & $\begin{array}{l}\text { districts, majority of the apple growers did not receive benefits from such government } \\
\text { services. In case of district Shopian and district Budgam, majority of the apple growers did } \\
\text { not avail benefitted from the facilities of "interest free credits" while as in case of district } \\
\text { Baramulla, majority of the apple growers were benefitted from the facilities of "Expert } \\
\text { guidance for orchard planning". }\end{array}$ \\
\hline
\end{tabular}

\section{Introduction}

India is endowed with vast variety of land, soil and agro-climatic conditions by nature which enables to produce varied type of crops. Agriculture is the back bone of the Indian economy and plays a vital role in the overall development of the nation and most of the Indian population is directly or indirectly involved in agriculture. Agricultural as well as horticultural sector is considered important for the overall development of the country. Achieving food and nutritional security is possible only by making use of new technologies in farm land. Today in most parts of the world, due to limited land and water resources, increase in production and quality food is hardly possible unless need based effective techniques in production system are adopted by the farmers. People have shifted towards non-conventional dietary pattern, using more of fruits, vegetables and 
other food items, which are rich in proteins etc.

Apple is commercially the most important temperate fruit and occupies the fourth $\left(4^{\text {th }}\right)$ position in the world in terms of production after banana, orange and grapes. China, USA and Turkey are the top three countries in the world as for as apple production is concerned, followed by Italy, India and Poland (Anonymous, 2016). India has emerged as one of the major producer of horticultural crops in the world.

Kashmir apple has lived up to its reputation for being one of the choicest fruits, Kashmir has for long been considered the home of apples. Kashmir valley is endowed with congenial agro-climatic conditions for a wide range of horticultural crops. The growth in area and production of horticultural crops like peach, pear, plum, and apple, is quite impressive. Jammu and Kashmir is rightly known as an apple state of India, contributing 4,200 crore to the state GDP (Anonymous, 2013).

\section{Materials and Methods}

\section{Sampling procedure}

A multistage sampling procedure was adopted for the selection of districts, horticultural zones, villages and sample apple growers.

\section{Selection of districts}

Kashmir valley consists of three regions namely Southern, Central and Northern region. Southern region of Kashmir valley consists of four districts viz., Anantnag, Kulgam, Pulwama, and Shopian. Central region consists of three districts viz., Srinagar, Budgam, and Ganderbal. Northern region consists of three districts viz., Bandipora, Baramulla and Kupwara. From each region, one district having maximum area under apple cultivation was selected purposively. District Shopian, district Budgam and district Baramulla having maximum area under apple cultivation were selected purposively from the respective regions.

\section{Selection of horticultural zones}

The respective districts were further divided into different horticultural zones, and from each district, three horticultural zones with maximum area under apple cultivation were selected purposively.

\section{Selection of villages}

From each horticultural zone, one village was selected purposively which were having maximum area under apple cultivation.

\section{Selection of orchardists}

A list of apple growers of selected villages were obtained from concerned Horticultural Development Offices and a sample of different orchardists (small, medium and large) were selected proportionately from selected villages.

Thus, a total of 300 orchardists (apple growers) from nine (9) villages were selected purposively. The structured interview schedule serves as a tool for collection of data. In view of this, an interview schedule was prepared on the basis of objective of the study. A structured interview schedule was developed in consultation with extension experts from department of horticulture, scientists of SKUAST-K/KVK's, available literature and mostly from the packages of practices recommended by SKUASTKashmir. Due care was taken while formulating the questions to be easy and clearly understood to the apple growers. The interview schedule was pretested prior to its 
finalization by the researcher in the nonsampled area for its practicability and relevancy. The data was collected by administering the pretested interview schedule to the apple growers. The information collected was transferred from the interview schedule to primary tables and to secondary tables. Qualitative data was quantified. From the quantified data, the frequency, percentage and different scores were worked out for further needful.

\section{Results and Discussion}

The data presented in table 1,2 and 3 revealed different services provided by government agencies for the benefit of apple production in different districts as discussed below.

\section{Facilitation of Interest free credit}

For "Facilitation of Interest free credit", it was observed from the data that in district Shopian, 64.36 percent of the apple growers had received the facilities of "interest free credits" and 35.64 percent of apple growers were not receiving any such facility. While as in district Budgam, 56.98 percent of the apple growers had received the facilities of "interest free credits" and 43.02 percent of apple growers were not receiving any such facility. In case of district Baramulla, 35.40 percent of the apple growers had received the facilities of "interest free credits" and 64.60 percent of apple growers were not receiving any such facility.

\section{Expert guidance for orchard planning}

For "Expert guidance for orchard planning", it was observed from the data, that in district Shopian 56.44 percent of the apple growers availed the benefit of "Expert guidance for orchard planning", while 43.56 percent of apple growers did not avail any such service.
While as, in district Budgam 26.74 percent of the apple growers availed the benefit of "Expert guidance for orchard planning" and 73.26 percent of apple growers did not avail any such service. In case of district Baramulla, 45.13 percent of the apple growers availed the benefit of "Expert guidance for orchard planning" and 54.87 percent of apple growers did not avail any such service, from the department.

\section{Preparation of orchard layout}

For "Preparation of orchard layout", it was revealed from the data that in district Shopian, 50.49 percent of the apple growers availed the services from the concerned department for "Preparation of orchard layout" and 49.50 percent of apple growers did not avail any such service. While as, in district Budgam, 31.40 percent of the apple growers availed the service for "Preparation of orchard layout" and 68.60 percent of apple growers did not avail any such service. In case of district Baramulla, 43.36 percent of the apple growers availed the service for "Preparation of orchard layout" and 56.64 percent of apple growers did not avail any such service.

\section{Subsidy on spray motors}

For "Subsidy on spray motors", it was observed from the data, that in district Shopian, 43.56 percent of the apple growers availed the service of department for "Subsidy on spray motors" and 56.44 percent of apple growers did not avail any such service. While as in district Budgam, 26.74 percent of the apple growers availed the service of department for "Subsidy on spray motors" and 64.60 percent of apple growers did not avail any such service.

In case of district Baramulla, 35.40 percent of the apple growers availed the service of department for "Subsidy on spray motors" 
and 06.46 percent of apple growers did not avail any such service.

\section{Organising farmer's tours}

For "Organising farmer's tours", it was observed from the data that in district Shopian, 36.63 percent of the apple growers were on "farmer's tours" in different states organised by the concerned department and 63.37 percent of apple growers did not receive any such service. While as, in district Budgam, 26.74 percent of the apple growers were on "farmer's tours" in different states organised by the concerned department and 73.26 percent of apple growers did not receive any such service. In case of district Baramulla, 25.66 percent of the apple growers were on "farmer's tours" in different states organised by the concerned department and 74.34 percent of apple growers did not receive any such service.

\section{Organising Kisan mela's, field visits etc.}

For "Organising Kisan mela's, field visits etc", it was observed from the data that in district Shopian, 33.66 percent of the apple growers were benefited from "Kisan mela's, field visits etc" organised by the horticulture department, KVK's and SKUAST Kashmir and 66.34 percent of apple growers did not benefit from such services. While as, in district Budgam, 22.09 percent of the apple growers were benefited from "Kisan mela's, field visits etc" organised by the horticulture department, KVK's and SKUAST Kashmir and 77.91 percent of apple growers did not benefit from such services. In case of district Baramulla, 21.24 percent of the apple growers were benefited from "Kisan mela's, field visits etc" organised by the horticulture department, KVK's and SKUAST Kashmir and 78.76 percent of apple growers did not benefit from such services.

\section{Subsidy on planting material}

For "Subsidy on Planting material", it was revealed from the data, that in district Shopian 32.67 percent of the apple growers availed the facility of "subsidy on planting material" and 67.33 percent of apple growers did not avail such facility. While as, in district Budgam, 15.12 percent of the apple growers availed the facility of subsidy on "Planting material" and 84.88 percent of apple growers did not receive any such facility. In case of district Baramulla, 25.66 percent of the apple growers availed the facility of subsidy on "Planting material" and 74.34 percent of apple growers did not receive any such facility.

\section{Subsidy on Poly-houses}

For "Subsidy on Poly-houses", it was observed from the data, that in district Shopian, 22.77 percent of the apple growers availed the facility of "Subsidy on Polyhouses" and 77.23 percent of apple growers did not receive any such facility. While as in district Budgam, 10.47 percent of the apple growers availed the facility of "Subsidy on Poly-houses" and 89.53 percent of apple growers did not receive any such facility.

In case of district Baramulla, 16.81 percent of the apple growers availed the facility of "Subsidy on Poly-houses" and 83.19 percent of apple growers did not receive any such facility.

\section{Subsidy on pruning and training tool kits}

For "Subsidy on pruning and training tool kits", it was observed from the data, that in district Shopian, 20.79 percent of the apple growers received the facility of "Subsidy on pruning and training tool kits" from the department and 79.21 percent of apple growers did not receive any such facility from the department. 
While as, in district Budgam, 08.14 percent of the apple growers received the facility of "Subsidy on pruning and training tool kits" from the department and 91.86 percent of apple growers did not receive any such facility from the department. In case of district Baramulla, 10.62 percent of the apple growers received the facility of "Subsidy on pruning and training tool kits" from the department and 89.38 percent of apple growers did not receive any such facility from the department.

\section{Subsidy on tillers, mini-tractors and tractors}

For "Subsidy on Tillers, mini-tractors and Tractors", it was observed from the data, that in district Shopian, 18.81 percent of the apple growers had received the subsidy on "Tillers, mini-tractors and Tractors" and 81.19 percent of apple growers had not received any such service. While as in district Budgam, 08.14 percent of the apple growers had received the subsidy on "Tillers, mini-tractors and Tractors" and 91.86 percent of apple growers had not received any such service.

In case of district Baramulla, 10.62 percent of the apple growers had received the subsidy on "Tillers, mini-tractors and Tractors" and 89.38 percent of apple growers had not received any such service.

\section{Facilitation of soil and water testing}

For "Facilitation of soil and water testing", it was observed from the data that in district Shopian 15.84 percent of the apple growers availed the services for "soil and water testing" and 84.16 percent of apple growers did not avail any such service. While as in district Budgam, 08.14 percent of the apple growers availed the facilities of "soil and water testing" and 91.86 percent of apple growers did not avail any such service. In case of district Baramulla, 20.35 percent of the apple growers availed the "soil and water testing" facilities and 79.65 percent of apple growers did not avail any such service.

\section{Facilitation of on-farm handling/sorting units}

For "Facilitation of On-Farm Handling/Sorting units", it was observed from the data that in district Shopian, 14.85 percent of the apple grower's availed facilities of "Handling/Sorting units" from the department and 85.15 percent of apple growers did not avail any such facility from the department. While as, in district Budgam 05.81 percent of the apple growers availed facilities of "Handling/Sorting units" from the department and 94.19 percent of apple growers did not avail any such facility from the department. In case of district Baramulla, 07.96 percent of the apple growers availed facilities of "Handling/Sorting units" from the department and 92.04 percent of apple growers did not avail any such facility from the department.

Further Perusal of the data presented in Table 04 represents the overall services rendered by the government agencies for the benefit of apple production in Kashmir.

In case of "Facilitation of interest free credit" it was found that 51.33 percent of apple growers had received the facilities of "interest free credits" and 48.67 percent of apple growers were not receiving any such facility. For "Expert guidance for orchard planning" it was found that 43.67 percent of apple growers availed the benefit from such facility and 56.33 percent of the apple growers did not avail any such facility. In case of "Preparation of orchard layout", it was observed from the data, that 42.33 percent of apple growers availed the services from the department for "Preparation of orchard layout" and 57.67 percent of the apple growers did not avail any 
such facility. For "Subsidy on spray motors", it was revealed that 35.67 percent of apple growers availed the services of the department for "Subsidy on spray motors" and 64.33 percent of the apple growers did not avail any such service. In case of "Organising farmer's tours", it was found that 29.67 percent of apple growers were on "farmer's tours" in different states organised by the concerned department and 70.33 percent of the apple growers did not receive any such service. For "Organising Kisan mela's, field visits etc", the data revealed that 25.67 percent of apple growers were benefited from "Kisan mela's, field visits etc" organised by the horticulture department, KVK's and SKUAST Kashmir and 74.33 percent of the apple growers were not benefitted from such services. For "Subsidy on Planting material", it was reflected from the data that 25.00 percent of apple growers availed the facility of subsidy on plant material and 75.00 percent of the apple growers did not avail any such facility. In case of "Subsidy on Poly-houses", it was revealed that 17.00 percent of apple growers availed the facility on "Subsidy on Poly-houses" and 83.00 percent of the apple growers did not receive any such facility. In case of "Subsidy on pruning and training tool kits", it was observed from the data, that 13.33 percent of the apple growers received the facility of "Subsidy on pruning and training tool kits" from the department and 86.67 percent of the apple growers did not receive any such facility from the department. For "Subsidy on tillers, mini-tillers and tractors", it was revealed that 12.67 percent of the apple growers had received "Subsidy on tillers, mini-tillers and tractors" and 87.33 percent of the apple growers did not receive any such service. In case of "Facilitation of soil and water testing" it was revealed that 15.33 percent of apple growers availed the services for soil and water testing and 84.67 percent of the apple growers did not receive any such service.

Table.1 Services rendered by the government agencies for the benefit of apple production in district Shopian $(n=101)$

\begin{tabular}{|c|l|c|c|c|c|}
\hline \multirow{2}{*}{$\begin{array}{c}\text { S. } \\
\text { No. }\end{array}$} & \multicolumn{1}{|c|}{ Services } & \multicolumn{2}{c|}{$\begin{array}{c}\text { Services } \\
\text { Availed }\end{array}$} & \multicolumn{2}{c|}{$\begin{array}{c}\text { Services not } \\
\text { Availed }\end{array}$} \\
\cline { 3 - 6 } & & No. & \%age & No. & \%age \\
\hline 1. & Facilitation of interest free credit. & $\mathbf{6 5}$ & 64.36 & $\mathbf{3 6}$ & 35.64 \\
\hline $\mathbf{2 .}$ & Expert guidance for orchard planning. & $\mathbf{5 7}$ & 56.44 & $\mathbf{4 4}$ & 43.56 \\
\hline 3. & Preparation of orchard layout. & $\mathbf{5 1}$ & 50.49 & $\mathbf{5 0}$ & 49.50 \\
\hline $\mathbf{4 .}$ & Subsidy on spray motors. & $\mathbf{4 4}$ & 43.56 & $\mathbf{5 7}$ & 56.44 \\
\hline $\mathbf{5 .}$ & Organising farmer's tours. & $\mathbf{3 7}$ & 36.63 & $\mathbf{6 4}$ & 63.37 \\
\hline $\mathbf{6 .}$ & Organising Kisan mela's, field visits etc. & $\mathbf{3 4}$ & 33.66 & $\mathbf{6 7}$ & 66.34 \\
\hline $\mathbf{7 .}$ & Subsidy on planting material. & $\mathbf{3 3}$ & 32.67 & $\mathbf{6 8}$ & 67.33 \\
\hline $\mathbf{8 .}$ & Subsidy on Poly-houses & $\mathbf{2 3}$ & 22.77 & $\mathbf{7 8}$ & 77.23 \\
\hline $\mathbf{9 .}$ & Subsidy on pruning and training tool kits. & $\mathbf{2 1}$ & 20.79 & $\mathbf{8 0}$ & 79.21 \\
\hline $\mathbf{1 0 .}$ & Subsidy on Tillers, mini-tractors, Tractors & $\mathbf{1 9}$ & 18.81 & $\mathbf{8 2}$ & 81.19 \\
\hline $\mathbf{1 1 .}$ & Facilitation of soil and water testing. & $\mathbf{1 6}$ & 15.84 & $\mathbf{8 5}$ & 84.16 \\
\hline $\mathbf{1 2}$ & Facilitation of On-Farm Handling/Sorting & $\mathbf{1 5}$ & 14.85 & $\mathbf{8 6}$ & 85.15 \\
\hline & units. & & & & \\
\hline
\end{tabular}


Table.2 Services rendered by the government agencies for the benefit of apple production in district Budgam

$(\mathbf{n}=\mathbf{8 6})$

\begin{tabular}{|c|c|c|c|c|c|}
\hline \multirow[t]{2}{*}{$\begin{array}{l}\text { S. } \\
\text { No. }\end{array}$} & \multirow[t]{2}{*}{ Services } & \multicolumn{2}{|c|}{$\begin{array}{c}\text { Services } \\
\text { Availed }\end{array}$} & \multicolumn{2}{|c|}{$\begin{array}{c}\text { Services not } \\
\text { Availed }\end{array}$} \\
\hline & & No. & $\%$ age & No. & $\%$ age \\
\hline 1. & Facilitation of interest free credit. & 49 & 56.98 & 37 & 43.02 \\
\hline 2. & Expert guidance for orchard planning. & 23 & 26.74 & 63 & 73.26 \\
\hline 3. & Preparation of orchard layout. & 27 & 31.40 & 59 & 68.60 \\
\hline 4. & Subsidy on spray motors. & 23 & 26.74 & 63 & 73.26 \\
\hline 5. & Organising farmer's tours. & 23 & 26.74 & 63 & 73.26 \\
\hline 6. & Organising Kisan mela's, field visits etc. & 19 & 22.09 & 67 & 77.91 \\
\hline 7. & Subsidy on planting material. & 13 & 15.12 & 73 & 84.88 \\
\hline 8. & Subsidy on Poly-houses. & 09 & 10.47 & 77 & 89.53 \\
\hline 9. & Subsidy on pruning and training tool kits. & 07 & 08.14 & 79 & 91.86 \\
\hline 10. & Subsidy on Tillers, mini-tractors, Tractors & 07 & 08.14 & 79 & 91.86 \\
\hline 11. & Facilitation of soil and water testing. & 07 & 08.14 & 79 & 91.86 \\
\hline 12. & $\begin{array}{l}\text { Facilitation of On-Farm Handling/Sorting } \\
\text { units. }\end{array}$ & 05 & 05.81 & 81 & 94.19 \\
\hline
\end{tabular}

Table.3 Services rendered by the government agencies for the benefit of apple production in district Baramulla

$(\mathbf{n}=113)$

\begin{tabular}{|c|l|c|c|c|c|}
\hline \multicolumn{1}{|c|}{$\begin{array}{c}\text { S. } \\
\text { No. }\end{array}$} & \multicolumn{1}{|c|}{ Services } & \multicolumn{2}{c|}{$\begin{array}{c}\text { Services } \\
\text { Availed }\end{array}$} & \multicolumn{2}{c|}{$\begin{array}{c}\text { Services not } \\
\text { Availed }\end{array}$} \\
\cline { 3 - 6 } & & No. & \%age & No. & \%age \\
\hline 1. & Facilitation of interest free credit. & $\mathbf{4 0}$ & 35.40 & $\mathbf{7 3}$ & 64.60 \\
\hline $\mathbf{2 .}$ & Expert guidance for orchard planning. & $\mathbf{5 1}$ & 45.13 & $\mathbf{6 2}$ & 54.87 \\
\hline $\mathbf{3 .}$ & Preparation of orchard layout. & $\mathbf{4 9}$ & 43.36 & $\mathbf{6 4}$ & 56.64 \\
\hline $\mathbf{4 .}$ & Subsidy on spray motors. & $\mathbf{4 0}$ & 35.40 & $\mathbf{7 3}$ & 64.60 \\
\hline $\mathbf{5 .}$ & Organising farmer's tours. & $\mathbf{2 9}$ & 25.66 & $\mathbf{8 4}$ & 74.34 \\
\hline $\mathbf{6 .}$ & Organising Kisan mela's, field visits etc. & $\mathbf{2 4}$ & 21.24 & $\mathbf{8 9}$ & 78.76 \\
\hline $\mathbf{7 .}$ & Subsidy on planting material. & $\mathbf{2 9}$ & 25.66 & $\mathbf{8 4}$ & 74.34 \\
\hline $\mathbf{8 .}$ & Subsidy on Poly-houses & $\mathbf{1 9}$ & 16.81 & $\mathbf{9 4}$ & 83.19 \\
\hline $\mathbf{9 .}$ & Subsidy on pruning and training tool kits. & $\mathbf{1 2}$ & 10.62 & $\mathbf{1 0 1}$ & 89.38 \\
\hline $\mathbf{1 0 .}$ & Subsidy on Tillers, mini-tractors, Tractors & $\mathbf{1 2}$ & 10.62 & $\mathbf{1 0 1}$ & 89.38 \\
\hline $\mathbf{1 1 .}$ & Facilitation of soil and water testing. & $\mathbf{2 3}$ & 20.35 & $\mathbf{9 0}$ & 79.65 \\
\hline $\mathbf{1 2}$ & Facilitation of On-Farm Handling/Sorting & $\mathbf{0 9}$ & 07.96 & $\mathbf{1 0 4}$ & 92.04 \\
\hline & units. & & & & \\
\hline
\end{tabular}


Table.4 Overall services rendered by the government agencies for the benefit of apple production

$(\mathbf{n}=300)$

\begin{tabular}{|c|c|c|c|c|c|}
\hline \multirow[t]{2}{*}{$\begin{array}{l}\text { S. } \\
\text { No. }\end{array}$} & \multirow[t]{2}{*}{ Services } & \multicolumn{2}{|c|}{$\begin{array}{l}\text { Services } \\
\text { Availed }\end{array}$} & \multicolumn{2}{|c|}{$\begin{array}{l}\text { Services not } \\
\text { Availed }\end{array}$} \\
\hline & & No. & $\%$ age & No. & $\%$ age \\
\hline 1. & Facilitation of interest free credit. & 154 & 51.33 & 146 & 48.67 \\
\hline 2. & Expert guidance for orchard planning. & 131 & 43.67 & 169 & 56.33 \\
\hline 3. & Preparation of orchard layout. & 127 & 42.33 & 173 & 57.67 \\
\hline 4. & Subsidy on spray motors. & 107 & 35.67 & 193 & 64.33 \\
\hline 5. & Organising farmer's tours. & 89 & 29.67 & 211 & 70.33 \\
\hline 6. & Organising Kisan mela's, field visits etc. & 77 & 25.67 & 223 & 74.33 \\
\hline 7. & Subsidy on planting material. & 75 & 25.00 & 225 & 75.00 \\
\hline 8. & Subsidy on Poly-houses & 51 & 17.00 & 249 & 83.00 \\
\hline 9. & Subsidy on pruning and training tool kits. & 40 & 13.33 & 260 & 86.67 \\
\hline 10. & Subsidy on Tillers, mini-tractors, Tractors. & 38 & 12.67 & 262 & 87.33 \\
\hline 11. & Facilitation of soil and water testing. & 46 & 15.33 & 254 & 84.67 \\
\hline 12. & $\begin{array}{l}\text { Facilitation of On-Farm Handling/Sorting } \\
\text { units. }\end{array}$ & 29 & 09.67 & 271 & 90.33 \\
\hline
\end{tabular}

Table.5 Rank wise comparison of services rendered by the government agencies for the benefit of apple production

\begin{tabular}{|c|l|c|c|c|c|}
\hline S. & \multicolumn{1}{|c|}{ Services } & \multicolumn{4}{c|}{ Rank } \\
\cline { 3 - 6 } No. & & Shopian & Budgam & Baramulla & Overall \\
\hline 1. & Facilitation of interest free credit. & I & I & III & I \\
\hline 2. & Expert guidance for orchard planning. & II & III & I & II \\
\hline 3. & Preparation of orchard layout. & III & II & II & III \\
\hline 4. & Subsidy on spray motors. & IV & III & III & IV \\
\hline 5. & Organising farmer's tours. & V & III & IV & V \\
\hline 6. & Organising Kisan mela's, field visits etc. & VI & IV & V & VI \\
\hline 7. & Subsidy on planting material. & VII & V & IV & VII \\
\hline 8. & Subsidy on Poly-houses & VIII & VI & VII & VIII \\
\hline 9. & Subsidy on pruning and training tool kits. & IX & VII & VIII & X \\
\hline 10. & Subsidy on Tillers, mini-tractors, Tractors. & X & VII & VIII & XI \\
\hline 11. & Facilitation of soil and water testing. & XI & VII & VI & IX \\
\hline 12. & Facilitation of On-Farm Handling/Sorting units. & XII & VIII & IX & XII \\
\hline
\end{tabular}

In case of "Facilitation of On-Farm Handling/Sorting units" it was revealed from the data that 09.67 percent of apple growers availed the facilities of "Handling/Sorting units" on their farms, from the department and 90.33 percent of the apple growers did not receive any such facility. 
Further from Table 5, which presents the rankwise comparison of services rendered by the government agencies for the benefit of apple production, it was revealed that majority of the apple growers from district Shopian and Budgam availed the benefits from "Facilitation of Interest free credit" with rank I and in district Baramulla, majority of the apple growers availed benefits from "Expert guidance for orchard planning" with rank I. While as in all the three districts (Shopian, Budgam and Baramulla) least benefit was received from "Facilitation of On-Farm Handling/Sorting units" with rank XII, VIII and IX respectively. For overall benefit of apple growers received from different services rendered by the government agencies, it was revealed, that majority of the apple growers availed the facilities of "Interest free credits" with rank I and least benefit was received from the facilities of "On-Farm Handling/Sorting units" with rank XII.

For "Subsidy on tillers, mini-tillers and tractors", it was revealed that 12.66 percent of the apple growers had received "Subsidy on tillers, mini-tillers and tractors" and 87.34 percent of the apple growers did not receive any such service. In case of "Facilitation of soil and water testing" it was revealed that 10.66 percent of apple growers availed the services for soil and water testing and 89.34 percent of the apple growers did not receive any such service. In case of "Facilitation of On-Farm Handling/Sorting units" it was revealed from the data that 09.33 percent of apple growers availed the facilities of "Handling/Sorting units" on their farms, from the department and 90.67 percent of the apple growers did not receive any such facility.
Further, in case of all the three districts (Shopian, Budgam and Baramulla), it was found that least number of the apple growers were benefited from "On-farm handling and sorting units", the possible reason for this is that low number of these units were provided by the government agencies and most of the services were provided to the apple growers with large land holdings. However, in Kashmir valley, majority of the apple growers were having marginal and small land holdings.

Further, it was found that majority of the apple growers in district Shopian were mostly benefited from such government schemes as compared to the apple growers of district Baramulla and district Budgam. The possible reason for this is that the apple growers in district Shopian and district Baramulla were having high extension contact, which results in high dissemination of information about different government schemes.

In conclusion, as it was found that among all the three districts majority of the apple growers did not benefit from different government services. So the need of the hour is that different Government services should be fully exploited by the apple growers. This is possible only when different extension agencies play the role by encouraging the apple growers and by providing them necessary support services.

\section{References}

Anonymous, (2013): Ministry of Agriculture, GOJK: Greater Kashmir-The local English daily: 12 November.

Anonymous, (2016): Top apple producing countries in the world: World atlas, published on July 21.

\section{How to cite this article:}

Zahoor Ahmad Shah, Mushtaq Ahmad Dar, Mohd Afzal Beigh, Showket Maqbool, Pradeep Kumar Singh and Sheikh Muzaffar Ahmad. 2019. Services Rendered by the Government Agencies for the Benefit of Apple Production in Kashmir, India. Int.J.Curr.Microbiol.App.Sci. 8(05): 2092-2100. doi: https://doi.org/10.20546/ijcmas.2019.805.244 